\title{
Review Article \\ Peroxisome Proliferator-Activated Receptors in Female Reproduction and Fertility
}

\author{
Maurizio Vitti, ${ }^{1}$ Giovanna Di Emidio, ${ }^{1}$ Michela Di Carlo, ${ }^{1}$ \\ Gaspare Carta, ${ }^{1,2}$ Andrea Antonosante, ${ }^{1}$ Paolo Giovanni Artini, ${ }^{3}$ Annamaria Cimini, ${ }^{1,4,5}$ \\ Carla Tatone, ${ }^{1,2}$ and Elisabetta Benedetti ${ }^{1}$
}

${ }^{1}$ Department of Life, Health and Environmental Sciences, University of L'Aquila, 67100 L'Aquila, Italy

${ }^{2}$ Gynecology and Fertility Unit, San Salvatore Hospital, 67100 L'Aquila, Italy

${ }^{3}$ Department of Experimental and Clinical Medicine, Division of Gynecology and Obstetrics, University of Pisa, Pisa, Italy

${ }^{4}$ Sbarro Institute for Cancer Research and Molecular Medicine and Center for Biotechnology, Temple University, Philadelphia, PA, USA

${ }^{5}$ National Institute for Nuclear Physics (INFN), Gran Sasso National Laboratory (LNGS), Assergi, Italy

Correspondence should be addressed to Elisabetta Benedetti; elisabetta.benedetti@univaq.it

Received 8 April 2016; Revised 1 June 2016; Accepted 19 June 2016

Academic Editor: Richard P. Phipps

Copyright (c) 2016 Maurizio Vitti et al. This is an open access article distributed under the Creative Commons Attribution License, which permits unrestricted use, distribution, and reproduction in any medium, provided the original work is properly cited.

Reproductive functions may be altered by the exposure to a multitude of endogenous and exogenous agents, drug or environmental pollutants, which are known to affect gene transcription through the peroxisome proliferator-activated receptors (PPARs) activation. PPARs act as ligand activated transcription factors and regulate metabolic processes such as lipid and glucose metabolism, energy homeostasis, inflammation, and cell proliferation and differentiation. All PPARs isotypes are expressed along the hypothalamic-pituitary-gonadal axis and are strictly involved in reproductive functions. Since female fertility and energy metabolism are tightly interconnected, the research on female infertility points towards the exploration of potential PPARs activating/antagonizing compounds, mainly belonging to the class of thiazolidinediones (TZDs) and fibrates, as useful agents for the maintenance of metabolic homeostasis in women with ovarian dysfunctions. In the present review, we discuss the recent evidence about PPARs expression in the hypothalamic-pituitary-gonadal axis and their involvement in female reproduction. Finally, the therapeutic potential of their manipulation through several drugs is also discussed.

\section{PPARs}

Peroxisome proliferator-activated receptors (PPARs) are ligand activated transcription factors belonging to the nuclear receptor family; three isotypes have been identified so far: $\operatorname{PPAR} \alpha, \operatorname{PPAR} \beta / \delta$, and PPAR $\gamma$, from frogs to humans [1]. A multitude of agents can bind the PPARs, influencing their activity. Endogenous compounds include arachidonic acid and its eicosanoid metabolites [2-4], while synthetic ligands are principally represented by fibrates (hypolipidemic drugs) [5], thiazolidinediones (TZDs) (antidiabetic drugs) [6], and nonsteroidal anti-inflammatory drugs [7]. PPARs can be also activated by environmental pollutants such as certain phthalate esters (plasticizers), herbicides, and organic solvents [8]. The binding specificity of these compounds towards PPAR subtypes is not strict; that is, several prostaglandins activate all three PPAR subtypes, while most fibrates and TZDs selectively bind to PPAR $\alpha$ and $\operatorname{PPAR} \gamma$, respectively [9]. After ligand binding, PPARs undergo a conformational change resulting in the dissociation of corepressors [10,11] and recruitment of coactivators [11]. PPARs heterodimerize with the 9-cis-retinoic acid X receptor (RXR, NR2B) to form PPAR/RXR complex that binds to a specific DNA sequence called PPAR-responsive element (PPRE), usually $5^{\prime}$-AACT AGGNCA A AGGTCA-3' [10]. The PPRE is usually located in the promoter region of key target 
genes mainly involved in lipid and cholesterol metabolism $[10,12,13]$, cell differentiation $[14,15]$, organogenesis [16], antiangiogenic activity [17], and insulin sensitization [18]. The PPAR family is known to adapt cell metabolism to lipid/glucose availability by controlling energy homeostasis genes. All three PPAR isotypes regulate endocrine pathways.

PPARs are expressed in the female hypothalamic-pituitary-gonadal axis and they act on critical processes for ovarian function. For instance, PPARs/RXRs may inhibit transactivation of the estrogen receptor through competition for ERE binding [19]. It is known in porcine ovarian follicles that PPAR $\gamma$ can downregulate aromatase expression through the suppression of NF- $\kappa$ B pathway [20] and that its synthetic activator rosiglitazone is able to stimulate PPAR $\gamma$ expression affecting the expression of important enzymes involved in steroidogenesis [21]. Regarding $\operatorname{PPAR} \alpha$, in vivo experiments in mouse ovaries showed that fenofibrate inhibits gene expression of enzymes involved in ovarian estrogen synthesis and that a functional PPAR $\alpha$ is indispensable for this inhibitory action [22].

All the three PPAR isotypes regulate gametogenesis, ovulation, corpus luteum regression, and the implantation process $[1,23]$. Regarding male gametogenesis mRNAs encoding $\operatorname{PPAR} \alpha, \operatorname{PPAR} \beta / \delta$, and PPAR $\gamma$ are developmentally expressed in both differentiating germ and Sertoli cells; particularly, PPAR $\gamma$ regulates the pattern of expression of key lipid metabolic genes in Sertoli cells [24].

In situ hybridization studies on rat ovary collected during follicular development and periovulatory period, by Komar and colleagues [25], demonstrated that PPAR $\gamma$ mRNA is localized primarily into granulosa cells and that its expression does not change during follicular development; in contrast the treatment of animals with human CG (hCG) leads after $24 \mathrm{~h}$ to a not uniform decrease of PPAR $\gamma$. Particularly, at $24 \mathrm{~h}$ after hCG the levels of PPAR $\gamma$ mRNA appeared reduced of $64 \%$, but some follicles maintained high expression. $\operatorname{PPAR} \alpha$ and $\operatorname{PPAR} \beta / \delta \mathrm{mRNA}$ levels, mainly present in theca and stroma cells, do not change even upon treatment. In vitro study confirmed that PPAR $\gamma$ is involved in follicular development, since, in granulosa cells from PMSG-primed rats cultured for $48 \mathrm{~h}$ with PPAR $\gamma$ ligands, an increase of progesterone and E2 secretion is observed [25].

The effect of PPAR $\gamma$ on progesterone synthesis depends on cell type, stage of cell differentiation, stage of the ovarian cycle, and/or animal species [26].

For instance, the role of PPAR $\gamma$ was investigated in corpora lutea of pseudopregnant rabbits at early, middle, and late stage. Both mRNA and protein levels of PPAR $\gamma$ decreased from the early to the late stage. In vitro studies on corpora lutea treated with PPAR $\gamma$ agonist show that the agonist is able to increase progesterone secretion and 3-beta-hydroxysteroid dehydrogenase (3-beta-HSD) activity at early and mid luteal stages, while decreasing at the same stages prostaglandinendoperoxide synthase 2 (PTGS2) activity and prostaglandin F2a. Treatments with a specific antagonist of PPAR $\gamma$ have opposite effects [27]. Quantitative analysis of PPARs mRNA in porcine endometrium through the estrous cycle and early pregnancy showed the presence of all three PPARs in this tissue. Particularly, this analysis showed a marked increase of PPAR $\gamma$ mRNA level on days 13-15 of the estrous cycle and the decrease of PPAR $\beta / \delta$ on days 11-12 of pregnancy suggesting that PPARs are engaged, respectively, in luteolysis (corpus luteum regression) and maternal recognition of pregnancy in the pig [28]. In addition, PPAR ligands affect progesterone (P4) and 17b-estradiol (E2) secretion by porcine corpus luteum during pregnancy [29].

$\operatorname{PPAR} \beta / \delta$ seems to play an important role in embryo implantation; in fact, several lines of evidence suggest that the effects of PGI2, the primary PG essential for implantation and decidualization, are mediated by $\operatorname{PPAR} \beta / \delta$ [30]. Moreover, using molecular, pharmacologic, and genetic approaches, Kang and colleagues, 2001, showed that PGI2-induced $\operatorname{PPAR} \beta / \delta$ activation accelerates blastocyst hatching in mice [31].

Furthermore, PPARs expression can be modulated by gonadotropin activity; that is, PPAR $\gamma$ mRNA and protein levels are tightly regulated in the ovary by luteinizing hormone (LH) in rat [32] and in rhesus monkey granulosa cells [33]. Particularly, the data obtained in primates showed that one of the initial actions of LH/CG on preovulatory follicle is to rapidly reduce PPAR $\gamma$ expression and its target gene $\mathrm{NR} 1 \mathrm{H} 3$, enzyme that promotes the expression of periovulatory genes, such as SCARB1 and STAR [33].

Moreover, gene array study conducted on human cumulus cells has revealed that PPAR $\alpha$ is among the genes differentially expressed when LH is supplemented to FSH during in vitro fertilization [34].

Recently we found differential effects of controlled ovarian stimulation COS protocols on PPARs and their steroidogenic targets in relation to $\mathrm{LH}$ and gonadotropin source. Particularly, the analyses of gene and protein expression of $\operatorname{PPAR} \alpha, \operatorname{PPAR} \beta / \delta$, and $\operatorname{PPAR} \gamma$ have revealed that $\mathrm{r}-\mathrm{hLH}$ associated with $\mathrm{r}$-hFSH exposure influence all the three PPARs by modulating the relative abundance of the different isotypes. In particular, a significant reduction of PPAR $\alpha$ protein was observed, although mRNA levels did not significantly change. PPAR $\beta / \delta$ and $\operatorname{PPAR} \gamma$ were significantly upregulated upon $\mathrm{r}-\mathrm{hFSH} / \mathrm{r}-\mathrm{hLH}$ treatment [35].

Finally, PPARs/RXRs, as exposed above, may inhibit transactivation of the estrogen receptor through competition for ERE binding mediating also the effects of the endocrine disruptors, many of which are PPAR ligands. These events may lead to infertility as demonstrated in many aquatic species and also in rodents. In fact, in several species, PPARs are expressed in somatic cells and germ cells of the ovary as well as the testis. Invalidation of these receptors in mice or stimulation of these receptors in vivo or in vitro showed that each receptor has physiological roles in the gamete maturation or the embryo development. In addition, synthetic PPAR $\gamma$ ligands are recently used to induce ovulation in women with polycystic ovary disease. These results reveal the positive actions of PPAR in reproduction. On the other hand, xenobiotics molecules (in herbicides, plasticizers, or components of personal care products), capable of activating PPAR, may disrupt normal PPAR functions in the ovary or the testis and have consequences on the quality of the gametes and the embryos [1]. 


\section{Female Reproductive System}

The female reproductive system requires precise coordination among the hypothalamic gonadotropin-releasing hormone $(\mathrm{GnRH})$, the pituitary gonadotropins, the ovaries, and the uterus. The pituitary gland responds to GnRH pulses by releasing two gonadotropins: follicle stimulating hormone (FSH) and luteinizing hormone (LH). The FSH activity during the early-midfollicular phase is critical for recruitment and maturation of ovarian follicles, expression of LH receptors, and differentiation of an endocrinologically active theca layer capable of synthesizing androgens in response to LH [36]. Androgens are then aromatized to estradiol by the granulosa cells. The increase of estradiol and ovarian production of the inhibins, peptides that inhibit pituitary gland synthesis and secretion of FSH, reduces FSH levels, enhances LH responsiveness, and induces the LH surge [37]. LH levels remain increased for 36-48 hours and ovulation occurs 16 to 20 hours after the peak of LH surge. Resumption of meiosis and progression to the second meiotic metaphase and polar body extrusion take place just prior to ovulation. After the release of the oocyte-cumulus complex, estradiol levels decline and luteinization of the follicle results in increased production of progesterone [38]. The rise in progesterone levels induces a significant decrease in $\mathrm{GnRH} / \mathrm{LH}$ pulse frequency and prepares the genital tract for a possible embryo implantation by increasing secretory activity of the endometrial glands and by changing composition of the cervical mucus that becomes thick and viscous [39]. Therefore, the ovarian cycle requires a fine coordination of the hypothalamicpituitary-gonadal axis and follicular growth to drive steroidogenesis that culminates in the ovulation of a fully competent oocyte. Altered secretion of gonadotropins and poor ovarian steroidal response are associated with reproductive dysfunctions [40,41] characterizing a large percentage of women who undergo in vitro fertilization (IVF) treatments. In IVF, the gonadotropin therapy plays a pivotal role in ovarian stimulation and influences egg retrieval, fertilization, embryo culture, and intrauterine transfer [42].

\section{The Role of PPARs in Female Reproductive Function}

A multitude of studies have revealed that PPARs are functionally expressed in the whole female reproductive system indicating that PPARs may play an important role in reproduction mostly due to their implication in energy homeostasis (Figure 1). Moreover, a role for PPARs has been evoked in ovarian dysfunctions related to obesity [43, 44], dyslipidemia $[45,46]$, hyperandrogenemia $[47-50]$, and insulin resistance [51-54].

3.1. Hypothalamic-Pituitary Axis. All PPAR isotypes are expressed in the mouse pituitary gland [55]; recent evidence in rats has demonstrated that fasting increases mRNA levels of PPAR $\alpha$ targets implicated in $\beta$-oxidation of fatty acids, such as acyl-CoA oxidase, carnitine palmitoyltransferase-1, medium chain acyl-CoA dehydrogenase, and ketogenesis, that is, mitochondrial 3-hydroxy-3-methylglutaryl-CoA synthase in the pituitary gland. Furthermore, studies on PPARa null mice have revealed that PPAR $\alpha$ increases pituitary production of prolactin and LH-beta genes upon fasting [56].

PPAR $\gamma$ is known to be highly expressed in normal human pituitary gland [57] and in the rat hypothalamus [58, 59]. It was reported that PPAR $\gamma$ activation by TZDs prevented the development of pituitary adenomas in mice and humans due to its antiproliferative effects, so TZDs are proposed as novel oral therapy for pituitary tumors [60]. PPAR $\gamma$ expression and function in the hypothalamopituitary-ovary axis in the sheep were studied by Froment and colleagues, 2003. They found that PPAR $\gamma$ is expressed in the pituitary gland but not in the hypothalamus and through transient transfection experiments on pituitary cells with a vector containing PPREs driving the firefly luciferase gene (PPRELuc); they found a small but significant effect of rosiglitazone on endogenous pituitary $\operatorname{PPAR} \gamma$, indicating that it is functional and could play a physiological role in this tissue [61]. Since the precise role of PPAR $\gamma$ in regulating the hypothalamic-pituitary-gonadal axis remains unclear, recently Sharma and colleagues, 2011, had tried to dissect the role of this transcriptional factor in the pituitary gland [62]. They showed that rosiglitazone downregulates GnRHmediated phosphorylation of the JNKs and p38MAPKs and Lhb and Fshb gene expression in L $\beta \mathrm{T} 2$ cells. Thus, the $\operatorname{PPAR} \gamma$ activation could act by reducing the basal activity of the gonadotropin gene promoters. Since these kinases are activated by many cytokines and inflammatory signals, the authors hypothesize that the TZD effect is consistent with its known anti-inflammatory actions. The same authors moreover showed that pituitary gland cre PPARg-knockout (PKO) mice have elevated plasma $\mathrm{LH}$ and reduced litter size compared to the control cre-negative littermates. Female PKO mice present also fertility defects like the transgenic mice with 10- to 12 -fold overexpression of a stabilized form of LH. These observations support a possible role for PPAR $\gamma$ in modulating pituitary gland function in vitro and in vivo.

As regards $\operatorname{PPAR} \beta / \delta$ very little is known about its role in this tissue.

3.2. Ovary. The basic unit of the ovary is the follicle, a functional syncytium formed by the oocyte and surrounding follicle cells. During reproductive life, a number of oocytes from the pool of quiescent follicles progress to mature and ovulate. Once recruited in the growing phase, primordial follicles develop into primary, secondary, and eventually antral follicle reaching the preovulatory stage under gonadotropin stimulation. The antral follicle is characterized by the presence of an antrum filled with follicular fluid bathing an oocyte surrounded by cumulus cells. The inner lining of the follicle is formed by granulosa cells, which are principally responsible for the androgens-estrogens conversion. The outer boundary is defined by theca cells, which form a vascularized cell layer that provides androgens to granulosa cells. Upon the LH surge, the dominant follicle ovulates the mature oocyte that 


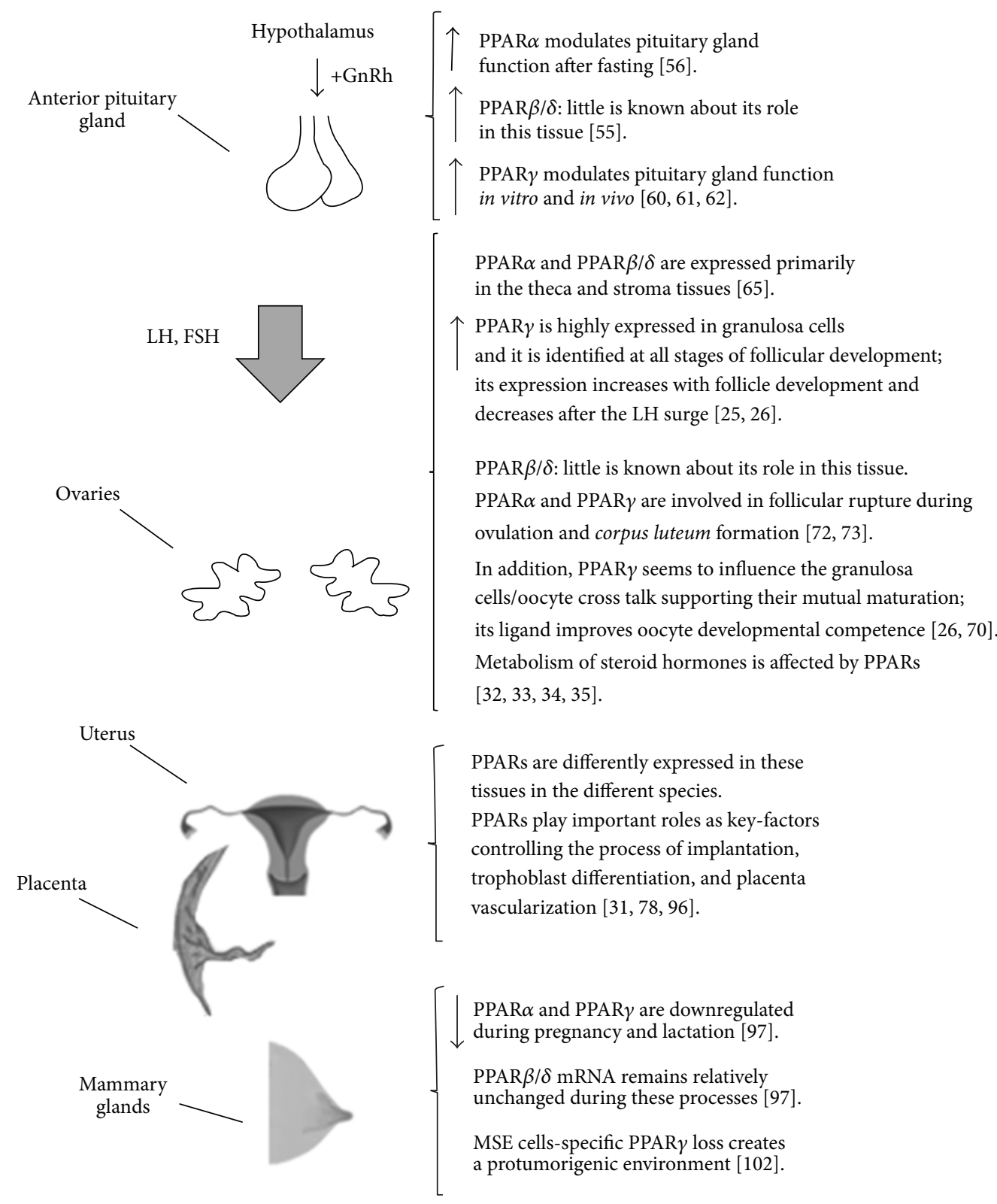

FIGURE 1: PPARs expression and role in the whole female reproductive system.

is ready for fertilization, whereas the remaining theca and granulosa cells become the corpus luteum that contributes to the production of circulating progesterone $[63,64]$. All PPAR isotypes have been observed in the ovarian tissue. $\operatorname{PPAR} \alpha$ and $\operatorname{PPAR} \beta / \delta$ are expressed primarily in the theca and stroma tissues [65]. PPAR $\gamma$ expression has been reported in the ovaries of mouse, rat, pig, sheep, cow, and humans, with higher levels in granulosa cells and lower levels in theca cells and corpus luteum of rodents and ruminants [66]. In particular, PPAR $\gamma$ has been identified in follicles at all stages of development and it has been shown that levels increase during follicle growth and decrease after the LH surge $[25,26]$. In the rat, PPAR $\gamma$ levels are lower in newly forming luteal tissue when compared with that in luteal tissue from previous ovulation [67]. PPAR $\gamma$ has also been identified in oocytes from cattle [68] and zebrafish [69], suggesting an evolutionary conserved role for this isotype in female germ cells. Since PPAR $\gamma$ expression is predominant in granulosa cells, it can be hypothesized that its activity influences the granulosa cell/oocyte cross talk, supporting their mutual maturation [26]. In this respect, some studies have investigated the possible effects of PPAR $\gamma$ activation on oocyte maturation. In vivo administration of PPAR $\gamma$ agonist rosiglitazone in diet-induced obese mice significantly improves oocyte competence supporting the conclusion that PPAR $\gamma$ positively affects ovarian functions [70]. However direct exposure to rosiglitazone does not produce the same effects in cumulus-oocyte complexes from normal mice. In this experimental system, although oocyte mitochondrial activity increases, fatty acid metabolism decreases and 
subsequent impairment of embryo development was observed [71]. The discrepancy between these studies may be explained by considering that beneficial effects of PPAR $\gamma$ activation in obese mice may result from systemic effects such as reduced circulating insulin and lipid. In addition it can be hypothesized that only oocytes with large lipid availability as those from obese mice may benefit from increased PPAR $\gamma$ activity. These observations may be useful for investigating potential ability of PPAR $\gamma$ agonists to improve oocyte competence following in vitro maturation in obese females. Finally, several proteases involved in follicular rupture during ovulation and corpus luteum formation, such as matrix metalloprotease-9, plasminogen activator, and plasminogen activator inhibitor, are regulated by PPAR $\alpha$ and $\operatorname{PPAR} \gamma[72,73]$. In contrast, very little is known about the role of PPAR $\beta / \delta$ in this tissue.

Regarding ovarian function, it is well documented that the synthesis and metabolism of steroid hormones are affected by all PPARs. PPAR $\alpha$ positively regulates $17 \beta$ hydroxysteroid dehydrogenase IV (17 $\beta$-HSD IV), the enzyme that catalyzes the conversion of $17 \beta$-estradiol to estrone, its inactive form [74]. Although PPAR $\alpha$ expression is very low in granulosa cells $[25,67]$, it was demonstrated that its activation is responsible for decreasing the expression and activity of aromatase [22]. In addition, dietary supplementation of dehydroepiandrosterone (DHEA), a PPAR $\alpha$ ligand and precursor of androstenedione, has recently emerged as a beneficial intervention for increasing oocyte quality in poor responders and aged women $[75,76]$. According to a model proposed by Ford [75], DHEA action may involve the activation of PPAR $\alpha$ target genes known to be critical for mitochondria functions. Thus, upregulation of PPAR $\alpha$ in the follicle microenvironment may support oxidative energy metabolism known to be jeopardized during physiological or pathological ovarian aging [77]. Moreover, the beneficial action by DHEA throughout PPAR $\alpha$ activation could be also ascribed to diminished levels of ceramide, a molecule involved in increased levels of apoptosis in aged follicles [75]. Furthermore, a gene array study conducted on human cumulus cells has revealed that PPAR $\alpha$ and $\operatorname{RXR} \beta$ were among the genes differentially expressed when LH is supplemented to FSH during IVF [34], thus highlighting their sensitivity to gonadotropins and suggesting their important role in follicle development as well as in steroidogenesis. In a recent study by our research group, we investigated the impact of different ovarian stimulation regimens based on $\mathrm{r}-\mathrm{hFSH}$ alone, $\mathrm{r}-\mathrm{hFSH} / \mathrm{r}-\mathrm{hLH}$, or highly purified human menopausal gonadotropin (hMG-HP) on gene and protein expression of PPAR isotypes and their targets relevant to steroid metabolism, such as 3-hydroxy-3-methylglutaryl coenzyme A reductase (HMG-CoA red), cytochrome P-450 (CYP19A1), $17 \beta$-hydroxysteroid dehydrogenase type IV (17 $\beta$ HSD IV), and $3 \beta$-hydroxysteroid dehydrogenase type 2 ( $3 \beta$ HSD II) in granulosa cells [35]. We also demonstrated that PPARs and their steroidogenic targets are influenced by the presence and source of LH in the ovarian stimulation protocol. These data revealed a key role of PPARs in the ovarian follicle growth and competence and widen the knowledge on the effects of ovarian stimulation protocol on ovarian physiology. In addition, it is well known that the action of cyclooxygenase 2(COX2-) derived prostacyclins which are factors essential for embryo development, hatching, and implantation $[30,31]$ is mediated by PPAR $\beta / \delta$. Indeed, blastocyst hatching is reduced in PPARb null mice and a beneficial effect of prostacyclin is observed in WT embryos and embryos exposed to a synthetic $\operatorname{PPAR} \beta / \delta$ ligand [78]. Therefore, PPAR $\beta / \delta$ may be considered as novel therapeutic target to improve IVF outcome.

An important effect of PPARs on steroidogenesis is related to the ability of PPAR $\gamma$ to counteract the interaction of NF- $\kappa \mathrm{B}$ with the aromatase promoter II [20] by inhibiting the expression of P-450 (CYP19A1), also known as aromatase or estrogen synthase, the rate limiting enzyme for the conversion of androgens to estradiol. In a recent study by Rak-Mardyła and Karpeta [21], it was observed in porcine ovarian follicles that rosiglitazone significantly increases PPAR $\gamma$ expression, progesterone secretion, $3 \beta$ HSDII activity, and protein expression but decreases androstenedione and testosterone secretion by reducing the expression and activity of 17-hydroxylase, 17,20-lyase (CYP17), and $17 \beta$ hydroxysteroid dehydrogenase (17 $\beta \mathrm{HSD}$ ) and had no effects on estradiol secretion and CYP19A1 activity. PPAR $\gamma$ can also affect steroidogenesis by decreasing the production of androgenic precursors in the theca cells, antagonizing the stimulation of androstenedione, typically induced by $\mathrm{LH} /$ insulin combination in disorders such as PCOS, hyperinsulinism, oligoovulation, and hirsutism [79]. Veldhuis and colleagues demonstrated that synthetic thiazolidinedione (troglitazone) and a natural ligand of PPAR $\gamma$ impede the concerted stimulation by LH and insulin of in vitro thecal cell androgen production, CYP17 gene expression, and CYP17 protein phosphorylation. In porcine ovaries resistin, the adipose tissue-specific secretory factor (ADSF) associated with ovarian dysfunction in obese women is known to upregulate $\operatorname{PPAR} \gamma$, which, in turn, reduces resistin expression. GW9662, a synthetic PPAR $\gamma$ antagonist, was capable of reversing the effect of resistin on steroid hormone secretion [80]. In mice, the ovarian tissue-specific deletion of PPAR $\gamma$ led to subfertility, principally due to a decreased number of implanted embryos and a decreased progesterone secretion by the corpus luteum [81].

\subsection{Uterus and Placenta. The expression of all PPAR isotypes} has been reported in uterus and placenta and a correlation between PPARs expression profiles in uterus and the development of placenta has been demonstrated [82]. A species-specific expression profile of PPAR isotypes has been observed. In sheep endometrium, PPAR $\alpha$ is mainly expressed during early stages of pregnancy with a decrease between day 7 and day 17 . PPAR $\beta / \delta$ is constantly expressed during pregnancy, whereas PPAR $\gamma$ expression is irregular [13]. In addition in this animal model, the expression of PPARs seems to be unrelated to the expression of RXRs, probably due to different heterodimer composition [83]. In rodents, PPAR $\alpha$ and $\operatorname{PPAR} \beta / \delta$ are expressed in the placenta labyrinth and junctional zone, whereas in humans, they are observed in villous trophoblasts and in particular in syncytiotrophoblasts [84]. In the rat, the expression of $\operatorname{PPAR} \beta / \delta$ is decreased in 
endometrial stromal cells during implantation [85]. PPAR $\gamma$ was also detected in mouse [86] and rat placenta [87] by days 8 and 11, respectively. In human placenta, PPAR $\gamma$ is expressed in early and full-term villous trophoblasts and in extravillous trophoblasts in first-trimester placentas [88]. In mice PPAR $\gamma$ is expressed in spongiotrophoblasts, in the vascular labyrinth necessary for maternal and fetal nutrient exchange. In cultured villous trophoblasts of human term placenta, PPAR $\alpha$ and $\operatorname{PPAR} \beta / \delta$ transcript levels were higher in cytotrophoblasts than in syncytiotrophoblasts [89]. PPAR $\gamma 1$ is the only PPAR $\gamma$ isoform clearly detectable in dog uterine/placental tissues. Placental expression of PPAR $\gamma$ is elevated after implantation and at midgestation, followed by a prepartal downregulation. All changes are more pronounced at the protein level suggesting that the PPAR $\gamma$ expression may be regulated at posttranscriptional level [90].

PPARa-knockout mice are associated with increased rates of maternal abortion, although surviving pups develop normally, while PPARg- and PPARb-knockout mice are embryonic-lethal due to gross placental abnormalities and defects in placental morphogenesis, respectively [91].

$\operatorname{PPAR} \beta / \delta$ null mutant mice showed defects in placenta development, probably due to the involvement of PPAR $\beta / \delta$ in differentiation of trophoblast giant cells [92]; in addition $\operatorname{PPAR} \beta / \delta$ is also known to regulate the production of COX2derived prostacyclin $\mathrm{I} 2$, which enhances mouse blastocyst invasion [78]. Moreover PGI2-induced PPAR $\beta / \delta$ activation accelerates blastocyst hatching in mice [31].

PPAR $\gamma$ in vivo and in vitro studies indicate that inactivation of PPAR $\gamma$ leads to defective trophoblast differentiation, early embryonic lethality, and severe developmental placental damage, which together can affect the placental labyrinth zone development [93-95]. For instance, PPAR $\gamma$ activity affects trophoblast differentiation by regulating the functions of both villocytotrophoblast (VCT) and extravillocytotrophoblast (EVCT) [91].

In conclusion we can assert that PPARs play important roles as key-factors responsible for controlling the process of placental development (for more details see review by Meher et al., 2015 [96]).

3.4. Mammary Glands. All three isotypes of PPAR are detected in rodent mammary gland and human breast cell lines [97, 98]. During pregnancy and lactation, PPAR $\alpha$ and PPAR $\gamma$ mRNAs decreased while PPAR $\beta / \delta$ mRNA remained relatively unchanged in mouse mammary gland [97]. Changes in PPAR $\gamma$ and endocrine-related genes in perfluorooctanoic acid (PFOA) treated mice delay mammary gland development at weaning [99]. PPAR $\gamma$ adipose tissue-specific knockout mice exhibit absence of dermal fat and absence of mammary gland development with loss of mammary fat pads, suggesting a critical role for PPAR $\gamma$ mammary gland development [100]. Moreover, its role in regulating the triacylglycerol synthesis and secretion in goat mammary cells outlines the functional importance of PPAR $\gamma$ in mammary gland tissue during lactation [101]. PPAR $\gamma$ loss in mammary secretory epithelial (MSE) cells results in decreased expression of PTEN and other factors contributing to a protumorigenic environment [102].

\section{PPAR Implications in Subfertility}

Female fertility and energy metabolism are tightly interconnected. During the reproductive life, the physiological activity of the gonads, with their cyclic production of sex hormones, ensures a continuous regulation of food intake and energy expenditure. In female mammals, alterations of gonadal activity, including age-dependent decrease of ovarian functions, are associated with disruption of metabolic homeostasis and consequent inflammatory reactions that trigger the onset of metabolic, cardiovascular, skeletal, and neural pathologies [103]. PCOS is a major metabolic and reproductive disorder characterized by hyperandrogenism, chronic anovulation, and polycystic ovaries [104], as well as metabolic disturbances. Half of PCOS patients have overweight or obesity [105] and dyslipidemia is also commonly observed [106]. Given the role of PPARs in regulating energy homeostasis and carbohydrate metabolism, there is an increasing interest in the use of its agonists for the restoration of metabolic homeostasis in women with ovarian dysfunction [107, 108]. Synthetic PPAR agonists are used for therapeutic treatment of metabolic diseases, including dyslipidemia [109], insulin resistance [110], and type 2 diabetes [111]. Particularly, fibrates, well-known PPAR $\alpha$ agonists, are commonly prescribed for the treatment of dyslipidemia [112]. Several TZDs, structural analogues of fibrates including pioglitazone and rosiglitazone, improve glycemic control in patients with type 2 diabetes or glucose intolerance via their insulin-sensitizing activity, mainly achieved by decreasing circulating fatty acids levels and increasing glucose uptake in insulin-sensitive tissues, like skeletal muscle. Current data show that TZDs can effectively reduce insulin and fasting blood glucose levels in patients with PCOS, but they do not effectively reduce androgen levels and seem to increase body weight [113]. A further study has reported that lowdose therapeutic regimen with rosiglitazone and metformin, a hypoglycemic drug used in the treatment of diabetes, has comparable beneficial impacts on metabolic, hormonal, and morphological features of PCOS [114]. Positive effects of pioglitazone, a PPAR $\gamma$ activator, on carnitine metabolism and insulin sensitivity in PCOS patients have been described [115]. Theca cells are the sole ovarian site of synthesis of DHEA, which is a precursor of androstenedione, an essential ligand for PPAR $\alpha$, and DHEA supplementation improves follicular microenvironment in poor responder patients [76]. Recent data have reported that administration of Irbesartan (IRB), a $\operatorname{PPAR} \gamma$ agonist, during chemotherapy alleviates the ovarian toxicity by cyclophosphamide (CPM), a chemotherapeutic agent. IRB coadministration restored ovarian antioxidant defences, such as increased glutathione (GSH) levels and superoxide dismutase (SOD) activity and decreased levels of malondialdehyde (MDA), an indicator of lipid peroxidation. In addition, the increase in E2 and reduction in FSH levels observed in IRB rats support the hypothesis that ovarian function is protected by activation of PPAR $\gamma$ signalling contributing to CPM detoxification and antioxidant response [116] that can be explored for future implications in oncofertility. In spite of the role of PPARs in ovarian homeostasis, it is important to highlight that toxic compounds such as 
industrial plasticizers, herbicides, and organic solvents can act as powerful PPAR agonists [8]. Unintended exposure to chemicals having PPAR $\alpha$ and PPAR $\gamma$ agonistic activities induces notable toxicological results, such as endocrine disruption [117]; particularly mono(2-ethylhexyl) phthalate MEHP is distinct from several structurally related phthalates but similar to the peroxisome proliferator $\mathrm{Wy}-14,643$ in its action on granulosa cell estradiol production.

Among various environmental chemicals, MEHP, a metabolite of dioctyl terephthalate bis(2-ethylhexyl) benzene-1,4dicarboxylate (DEHP), transactivates PPAR $\alpha$ and PPAR $\gamma$ in both human and mouse [118]; the triphenyltin, used as fungicide, acts as a ligand of PPAR $\gamma$ [119]; diclofop-methyl and pyrethrins, two common pesticides, induce PPAR $\alpha$ agonistic activity in vivo as well as in vitro [120].

In a recent study the effect of the exposure to DEHP on ovarian expression of estrogen receptor $\alpha$ (Esrl) and aromatase (Cyp19al) in three generations of Sv/129 wild-type $(\mathrm{WT},+/+)$ and PPAR $\alpha(-/-)$ knockout mice is investigated. Ovarian expression of Esrl decreases in response to DEHP treatment in all WT generations, but in PPAR $\alpha$ null mice this treatment was ineffective, suggesting that transgenerational repression of ovarian Esrl gene expression by DEHP is mediated by PPAR $\alpha$-dependent pathways [121].

\section{Future Perspective}

In conclusion, a large number of studies have demonstrated that PPARs might play an important role in female reproduction, including ovarian function, gestation, and communication between mother and fetus. The use of synthetic PPAR ligands employed to ameliorate complications related to metabolic disorders has recently been expanded to disorders in the reproductive area. Moreover, the correlation between PPARs and steroidogenesis during follicular differentiation supports further research aimed at understanding if controlled ovarian hyperstimulation in IVF cycles may benefit from their pharmacological manipulation. Nevertheless, research in this field needs to be associated with the knowledge of mechanisms underlying deleterious effects on fertility of uncontrolled exposure to PPAR synthetic ligands.

In conclusion, PPARs are new players in the field of reproduction being expressed and functional in a variety of animal reproductive tissues. In addition, from studies with PCOS women $[115,116]$, it is now clarified that ligands of PPARs ameliorate fertility. However, the knowledge on expression and function of PPARs and its ligands in other diseases linked to infertility and disturbed pregnancy is limited and deserves further investigations, especially in humans.

\section{Abbreviations}

ADSF: Adipose tissue-specific secretory factor

COS: Controlled ovarian stimulation

COX2: Cyclooxygenase 2

CPM: Cyclophosphamide
CYP17: $\quad$ Cytochrome P450

17-alpha-hydroxylase/17,20-lyase

CYP19A1: Cytochrome P-450

DEHP: Di-2-ethylhexylphthalate

E2: $\quad 17 b$-estradiol

ERE: $\quad$ Estrogen response element

Esrl: $\quad$ Estrogen receptor $\alpha$

EVCTS: $\quad$ Extravillous cytotrophoblast

Fshb: $\quad$ Follicle stimulating hormone, beta

polypeptide

FSH: $\quad$ Follicle stimulating hormone

GnRH: Gonadotropin realising hormone

hCG: Human CG

HMG-CoA red: 3-Hydroxy-3-methylglutaryl coenzyme A reductase

hMG-HP: $\quad$ Highly purified human menopausal

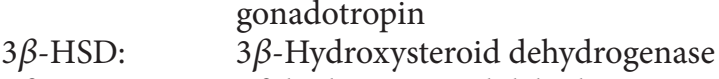

$3 \beta$ HSD II: $\quad 3 \beta$-hydroxysteroid dehydrogenase

17 $\beta$ HSD IV: $\quad 17 \beta$-Hydroxysteroid dehydrogenase type

IV

IRB: Ibersartan

IVF: $\quad$ In vitro fertilization

LH: $\quad$ Luteinizing hormone

Lhb: Luteinizing hormone beta polypeptide

LH/CG: Luteinizing

hormone/choriogonadotropin

MDA: $\quad$ Malondialdehyde

MEHP: $\quad$ Mono(2-ethylhexyl) phthalate

MSE: $\quad$ Mammary secretory epithelial

NF- $\kappa$ B: $\quad$ Nuclear Factor Kappa B

NR1H3: Nuclear receptor subfamily 1 , group $H$, member 3

PCOS: $\quad$ Polycystic ovary syndrome

PFOA: Perfluorooctanoic acid

PG: $\quad$ Prostaglandin

PGI2: $\quad$ Prostacyclin

PKO: $\quad$ Perforin knockout

PMSG: $\quad$ Pregnant mare's serum gonadotropin

PPRE: $\quad$ PPAR-responsive element

PTGS2: $\quad$ Prostaglandin-endoperoxide synthase 2

r-hFSH: Recombinant human follicle stimulating

hormone

r-hLH: Recombinant human luteinizing hormone

SCARB1: $\quad$ Scavenger receptor class B member 1

SOD: $\quad$ Superoxide dismutase

STAR: $\quad$ Steroidogenic acute regulatory protein

TZDs: $\quad$ Thiazolidinediones

VCTs: Villous cytotrophoblasts.

\section{Competing Interests}

The authors confirm that this paper content has no competing interests.

\section{References}

[1] J.-C. Huang, "The role of peroxisome proliferator-activated receptors in the development and physiology of gametes and 
preimplantation embryos," PPAR Research, vol. 2008, Article ID 732303, 7 pages, 2008.

[2] B. M. Forman, P. Tontonoz, J. Chen, R. P. Brun, B. M. Spiegelman, and R. M. Evans, "15-Deoxy- $\Delta^{12},{ }^{14}$-prostaglandin $\mathrm{J}_{2}$ is a ligand for the adipocyte determination factor PPAR $\gamma$," Cell, vol. 83, no. 5, pp. 803-812, 1995.

[3] B. M. Forman, J. Chen, and R. M. Evans, "Hypolipidemic drugs, polyunsaturated fatty acids, and eicosanoids are ligands for peroxisome proliferator-activated receptors $\alpha$ and $\delta$," Proceedings of the National Academy of Sciences of the United States of America, vol. 94, no. 9, pp. 4312-4317, 1997.

[4] S. A. Kliewer, J. M. Lenhard, T. M. Willson, I. Patel, D. C. Morris, and J. M. Lehmann, "A prostaglandin $\mathbf{J}_{2}$ metabolite binds peroxisome proliferator-activated receptor $\gamma$ and promotes adipocyte differentiation," Cell, vol. 83, no. 5, pp. 813-819, 1995.

[5] G. Krey, O. Braissant, F. L'Horset et al., "Fatty acids, eicosanoids, and hypolipidemic agents identified as ligands of peroxisome proliferator-activated receptors by coactivator-dependent receptor ligand assay," Molecular Endocrinology, vol. 11, no. 6, pp. 779-791, 1997.

[6] J. M. Lehmann, L. B. Moore, T. A. Smith-Oliver, W. O. Wilkison, T. M. Willson, and S. A. Kliewer, "An antidiabetic thiazolidinedione is a high affinity ligand for peroxisome proliferatoractivated receptor $\gamma$ (PPAR $\gamma)$," The Journal of Biological Chemistry, vol. 270, no. 22, pp. 12953-12956, 1995.

[7] J. M. Lehmann, J. M. Lenhard, B. B. Oliver, G. M. Ringold, and S. A. Kliewer, "Peroxisome proliferator-activated receptors $\alpha$ and $\gamma$ are activated by indomethacin and other non-steroidal antiinflammatory drugs," The Journal of Biological Chemistry, vol. 272, no. 6, pp. 3406-3410, 1997.

[8] T. Nakajima, G. Ichihara, M. Kamijima, S. Itohara, and T. Aoyama, "Functional activation of peroxisome proliferatoractivated receptor alpha (PPARalpha) by environmental chemicals in relation to their toxicities," Nagoya Journal of Medical Science, vol. 65, no. 3-4, pp. 85-94, 2002.

[9] K. Yu, W. Bayona, C. B. Kallen et al., "Differential activation of peroxisome proliferator-activated receptors by eicosanoids," The Journal of Biological Chemistry, vol. 270, no. 41, pp. 2397523983, 1995.

[10] P. Escher and W. Wahli, "Peroxisome proliferator-activated receptors: insight into multiple cellular functions," Mutation Research/Fundamental and Molecular Mechanisms of Mutagenesis, vol. 448, no. 2, pp. 121-138, 2000.

[11] Y. Zhu, L. Kan, C. Qi et al., "Isolation and characterization of peroxisome proliferator-activated receptor (PPAR) interacting protein (PRIP) as a coactivator for PPAR," The Journal of Biological Chemistry, vol. 275, no. 18, pp. 13510-13516, 2000.

[12] J. M. Peters, S. S. T. Lee, W. Li et al., "Growth, adipose, brain, and skin alterations resulting from targeted disruption of the mouse peroxisome proliferator-activated receptor $\beta(\delta)$," Molecular and Cellular Biology, vol. 20, no. 14, pp. 5119-5128, 2000.

[13] J. Yang, L. Chen, X. Zhang et al., "PPARs and female reproduction: evidence from genetically manipulated mice," $P P A R$ Research, vol. 2008, Article ID 723243, 8 pages, 2008.

[14] P. Tontonoz, E. Hu, and B. M. Spiegelman, "Regulation of adipocyte gene expression and differentiation by peroxisome proliferator activated receptor $\gamma$," Current Opinion in Genetics and Development, vol. 5, no. 5, pp. 571-576, 1995.

[15] A. Bernardo, R. De Simone, C. De Nuccio, S. Visentin, and L. Minghetti, "The nuclear receptor peroxisome proliferatoractivated receptor- $\gamma$ promotes oligodendrocyte differentiation through mechanisms involving mitochondria and oscillatory $\mathrm{Ca}^{2+}$ waves," Biological Chemistry, vol. 394, no. 12, pp. 1607-1614, 2013.

[16] S. Yu, L. Levi, R. Siegel, and N. Noy, "Retinoic acid induces neurogenesis by activating both retinoic acid receptors (RARs) and peroxisome proliferator-activated receptor $\beta / \delta(\operatorname{PPAR} \beta / \delta)$," The Journal of Biological Chemistry, vol. 287, no. 50, pp. 4219542205, 2012.

[17] E. Scoditti, M. Massaro, M. A. Carluccio, A. Distante, C. Storelli, and R. De Caterina, "PPAR $\gamma$ agonists inhibit angiogenesis by suppressing $\mathrm{PKC} \alpha$-and CREB-mediated COX-2 expression in the human endothelium," Cardiovascular Research, vol. 86, no. 2, pp. 302-310, 2010.

[18] C. Martinez Calejman, J. M. Di Gruccio, M. E. Mercau et al., "Insulin sensitization with a peroxisome proliferator-activated receptor $\gamma$ agonist prevents adrenocortical lipid infiltration and secretory changes induced by a high-sucrose diet," Journal of Endocrinology, vol. 214, no. 3, pp. 267-276, 2012.

[19] H. Keller, F. Givel, M. Perroud, and W. Wahli, "Signaling cross-talk between peroxisome proliferator-activated receptor/ retinoid $\mathrm{X}$ receptor and estrogen receptor through estrogen response elements," Molecular Endocrinology, vol. 9, no. 7, pp. 794-804, 1995.

[20] W. Fan, T. Yanase, H. Morinaga et al., "Activation of peroxisome proliferator-activated receptor- $\gamma$ and retinoid $\mathrm{X}$ receptor inhibits aromatase transcription via nuclear factor- $\kappa \mathrm{B}$," Endocrinology, vol. 146, no. 1, pp. 85-92, 2005.

[21] A. Rak-Mardyła and A. Karpeta, "Rosiglitazone stimulates peroxisome proliferator-activated receptor gamma expression and directly affects in vitro steroidogenesis in porcine ovarian follicles," Theriogenology, vol. 82, no. 1, pp. 1-9, 2014.

[22] K. Toda, T. Okada, C. Miyaura, and T. Saibara, "Fenofibrate, a ligand for PPAR $\alpha$, inhibits aromatase cytochrome P450 expression in the ovary of mouse," Journal of Lipid Research, vol. 44, no. 2, pp. 265-270, 2003.

[23] L. M. Vélez, G. A. Abruzzese, and A. B. Motta, "The biology of the peroxisome proliferator-activated receptor system in the female reproductive tract," Current Pharmaceutical Design, vol. 19, no. 25, pp. 4641-4646, 2013.

[24] K. Thomas, D. Y. Sung, X. Chen et al., "Developmental patterns of PPAR and RXR gene expression during spermatogenesis," Frontiers in Bioscience, vol. 3, pp. 1209-1220, 2011.

[25] C. M. Komar, O. Braissant, W. Wahli, and T. E. Curry Jr., "Expression and localization of PPARs in the rat ovary during follicular development and the periovulatory period," Endocrinology, vol. 142, no. 11, pp. 4831-4838, 2001.

[26] C. M. Komar, "Peroxisome proliferator-activated receptors (PPARs) and ovarian function-implications for regulating steroidogenesis, differentiation, and tissue remodeling," Reproductive Biology and Endocrinology, vol. 3, article 41, 2005.

[27] M. Zerani, M. Maranesi, G. Brecchia, A. Gobbetti, C. Boiti, and F. Parillo, "Evidence for a luteotropic role of peroxisome proliferator-activated receptor gamma: expression and in vitro effects on enzymatic and hormonal activities in corpora lutea of pseudopregnant rabbits," Biology of Reproduction, vol. 88, no. 3, article 62, 2013.

[28] I. Bogacka and M. Bogacki, "The quantitative expression of peroxisome proliferator activated receptor (PPAR) genes in porcine endometrium through the estrous cycle and early pregnancy," Journal of Physiology and Pharmacology, vol. 62, no. 5, pp. 559-565, 2011. 
[29] A. Kurzynska, M. Bogacki, K. Chojnowska, and I. Bogacka, "Peroxisome proliferator activated receptor ligands affect progesterone and $17 \beta$-estradiol secretion by porcine corpus luteum during early pregnancy," Journal of Physiology and Pharmacology, vol. 65, no. 5, pp. 709-717, 2014.

[30] H. Lim, R. A. Gupta, W.-G. Ma et al., "Cyclo-oxygenase2-derived prostacyclin mediates embryo implantation in the mouse via PPAR $\delta$," Genes and Development, vol. 13, no. 12, pp. 1561-1574, 1999.

[31] H. J. Kang, S. J. Hwang, J. A. Yoon et al., "Activation of peroxisome proliferatorsactivated receptor $\delta(\operatorname{PPAR} \delta)$ promotes blastocyst hatching in mice," Molecular Human Reproduction, vol. 17, no. 10, pp. 653-660, 2011.

[32] J. Banerjee and C. M. Komar, "Effects of luteinizing hormone on peroxisome proliferator-activated receptor $\gamma$ in the rat ovary before and after the gonadotropin surge," Reproduction, vol. 131, no. 1, pp. 93-101, 2006.

[33] M. Puttabyatappa, C. A. Vandevoort, and C. L. Chaffin, "hCGinduced down-regulation of PPAR $\gamma$ and liver $\mathrm{X}$ receptors promotes periovulatory progesterone synthesis by macaque granulosa cells," Endocrinology, vol. 151, no. 12, pp. 5865-5872, 2010.

[34] V. Gatta, C. Tatone, R. Ciriminna et al., "Gene expression profiles of cumulus cells obtained from women treated with recombinant human luteinizing hormone + recombinant human follicle-stimulating hormone or highly purified human menopausal gonadotropin versus recombinant human folliclestimulating hormone alone," Fertility and Sterility, vol. 99, no. 7, pp. 2000.el-2008.e1, 2013.

[35] C. Tatone, E. Benedetti, M. Vitti et al., "Modulating intrafollicular hormonal milieu in controlled ovarian stimulation: insights from PPAR expression in human granulosa cells," Journal of Cellular Physiology, vol. 231, no. 4, pp. 908-914, 2016.

[36] S. A. Tonetta and G. S. DiZerega, "Intragonadal regulation of follicular maturation," Endocrine Reviews, vol. 10, no. 2, pp. 205229, 1989.

[37] H. C. Burger, "Evidence for a negative feedback role of inhibin in follicle stimulating hormone regulation in women," Human Reproduction, vol. 8, supplement 2, pp. 129-132, 1993.

[38] M. C. Batista, T. P. Cartledge, A. W. Zellmer, L. K. Nieman, G. R. Merriam, and D. L. Loriaux, "Evidence for a critical role of progesterone in the regulation of the midcycle gonadotropin surge and ovulation," Journal of Clinical Endocrinology and Metabolism, vol. 74, no. 3, pp. 565-570, 1992.

[39] D. A. Van Vugt, N. Y. Lam, and M. Ferin, "Reduced frequency of pulsatile luteinizing hormone secretion in the luteal phase of the rhesus monkey. Involvement of endogenous opiates," Endocrinology, vol. 115, no. 3, pp. 1095-1101, 1984.

[40] A. Barria, V. Leyton, S. R. Ojeda, and H. E. Lara, "Ovarian steroidal response to gonadotropins and beta-adrenergic stimulation is enhanced in polycystic ovary syndrome: role of sympathetic innervation," Endocrinology, vol. 133, no. 6, pp. 26962703, 1993.

[41] R. J. Chang and H. Cook-Andersen, "Disordered follicle development," Molecular and Cellular Endocrinology, vol. 373, no. 1-2, pp. 51-60, 2013.

[42] R. B. Leão and S. C. Esteves, "Gonadotropin therapy in assisted reproduction: an evolutionary perspective from biologics to biotech," Clinics, vol. 69, no. 4, pp. 279-293, 2014.

[43] A. M. Pohlmeier, J. L. Phy, P. Watkins et al., "Effect of a lowstarch/low-dairy diet on fat oxidation in overweight and obese women with polycystic ovary syndrome," Applied Physiology, Nutrition and Metabolism, vol. 39, no. 11, pp. 1237-1244, 2014.

[44] E. Ngadjui, P. A. Nkeng-Efouet, T. B. Nguelefack, A. Kamanyi, and P. Watcho, "High fat diet-induced estrus cycle disruption: effects of Ficus asperifolia," Journal of Complementary and Integrative Medicine, vol. 12, no. 3, pp. 205-215, 2015.

[45] T. H.-W. Huang and B. D. Roufogalis, "Healing the diabetic heart: modulation of cardiometabolic syndrome through peroxisome proliferator activated receptors (PPARs)," Current Molecular Pharmacology, vol. 5, no. 2, pp. 241-247, 2012.

[46] A. Tsur, R. Orvieto, J. Haas, A. Kedem, and R. Machtinger, "Does bariatric surgery improve ovarian stimulation characteristics, oocyte yield, or embryo quality?" Journal of Ovarian Research, vol. 7, no. 1, article 116, 2014.

[47] M. Pusalkar, P. Meherji, J. Gokral, S. Chinnaraj, and A. Maitra, "CYP11A1 and CYP17 promoter polymorphisms associate with hyperandrogenemia in polycystic ovary syndrome," Fertility and Sterility, vol. 92, no. 2, pp. 653-659, 2009.

[48] J. S. Collins, J. P. Beller, C. Burt Solorzano et al., "Blunted daynight changes in luteinizing hormone pulse frequency in girls with obesity: the potential role of hyperandrogenemia," Journal of Clinical Endocrinology and Metabolism, vol. 99, no. 8, pp. 2887-2896, 2014.

[49] W. K. McGee, C. V. Bishop, C. R. Pohl et al., "Effects of hyperandrogenemia and increased adiposity on reproductive and metabolic parameters in young adult female monkeys," American Journal of Physiology-Endocrinology and Metabolism, vol. 306, no. 11, pp. E1292-E1304, 2014.

[50] L. M. Banu, D. Begum, S. A. Rahman, F. H. Mollah, S. Ferdousi, and M. Habibullah, "Correlation of hyperinsulinemia with hyperandrogenemia in primary infertile women with polycystic ovary syndrome," Mymensingh Medical Journal, vol. 24, no. 1, pp. 127-132, 2015.

[51] M. Belani, N. Purohit, P. Pillai, S. Gupta, and S. Gupta, "Modulation of steroidogenic pathway in rat granulosa cells with subclinical Cd exposure and insulin resistance: an impact on female fertility," BioMed Research International, vol. 2014, Article ID 460251, 13 pages, 2014.

[52] D. H. Kort, A. Kostolias, C. Sullivan, and R. A. Lobo, "Chemerin as a marker of body fat and insulin resistance in women with polycystic ovary syndrome," Gynecological Endocrinology, vol. 31, no. 2, pp. 152-155, 2015.

[53] S. B. Mayer, W. S. Evans, and J. E. Nestler, "Polycystic ovary syndrome and insulin: our understanding in the past, present and future," Women's Health, vol. 11, no. 2, pp. 137-149, 2015.

[54] V. Turan, E. D. Sezer, B. Zeybek, and F. Sendag, "Infertility and the presence of insulin resistance are associated with increased oxidative stress in young, non-obese turkish women with polycystic ovary syndrome," Journal of Pediatric and Adolescent Gynecology, vol. 28, no. 2, pp. 119-123, 2015.

[55] A. L. Bookout, Y. Jeong, M. Downes, R. T. Yu, R. M. Evans, and D. J. Mangelsdorf, "Anatomical profiling of nuclear receptor expression reveals a hierarchical transcriptional network," Cell, vol. 126, no. 4, pp. 789-799, 2006.

[56] B. König, C. Rauer, S. Rosenbaum, C. Brandsch, K. Eder, and G. I. Stangl, "Fasting upregulates PPAR $\alpha$ target genes in brain and influences pituitary hormone expression in a PPAR $\alpha$ dependent manner," PPAR Research, vol. 2009, Article ID 801609, 9 pages, 2009.

[57] F. Bogazzi, D. Russo, M. T. Locci et al., "Peroxisome proliferatoractivated receptor (PPAR) $\gamma$ is highly expressed in normal 
human pituitary gland," Journal of Endocrinological Investigation, vol. 28, no. 10, pp. 899-904, 2005.

[58] A. Mouihate, L. Boissé, and Q. J. Pittman, "A novel antipyretic action of 15-deoxy- $\Delta$ 12,14-prostaglandin J2 in the rat brain," Journal of Neuroscience, vol. 24, no. 6, pp. 1312-1318, 2004.

[59] G. Wiesner, B. A. Morash, E. Ur, and M. Wilkinson, "Food restriction regulates adipose-specific cytokines in pituitary gland but not in hypothalamus," Journal of Endocrinology, vol. 180, no. 3, pp. R1-R6, 2004.

[60] A. P. Heaney, M. Fernando, and S. Melmed, "PPAR- $\gamma$ receptor ligands: novel therapy for pituitary adenomas," Journal of Clinical Investigation, vol. 111, no. 9, pp. 1381-1388, 2003.

[61] P. Froment, S. Fabre, J. Dupont et al., "Expression and functional role of peroxisome proliferator-activated receptor- $\gamma$ in ovarian folliculogenesis in the sheep," Biology of Reproduction, vol. 69, no. 5, pp. 1665-1674, 2003.

[62] S. Sharma, P. M. Sharma, D. S. Mistry et al., "PPARG regulates gonadotropin-releasing hormone signaling in LbetaT2 cells in vitro and pituitary gonadotroph function in vivo in mice," Biology of Reproduction, vol. 84, no. 3, pp. 466-475, 2011.

[63] D. Adhikari and K. Liu, "Molecular mechanisms underlying the activation of mammalian primordial follicles," Endocrine Reviews, vol. 30, no. 5, pp. 438-464, 2009.

[64] A. R. Baerwald, G. P. Adams, and R. A. Pierson, "Ovarian antral folliculogenesis during the human menstrual cycle: a review," Human Reproduction Update, vol. 18, no. 1, pp. 73-91, 2012.

[65] S. S.-T. Lee, T. Pineau, J. Drago et al., "Targeted disruption of the $\alpha$ isoform of the peroxisome proliferator-activated receptor gene in mice results in abolishment of the pleiotropic effects of peroxisome proliferators," Molecular and Cellular Biology, vol. 15, no. 6, pp. 3012-3022, 1995.

[66] P. Froment, F. Gizard, D. Defever, B. Staels, J. Dupont, and P. Monget, "Peroxisome proliferator-activated receptors in reproductive tissues: from gametogenesis to parturition," Journal of Endocrinology, vol. 189, no. 2, pp. 199-209, 2006.

[67] C. M. Komar and T. E. Curry Jr., "Localization and expression of messenger RNAs for the peroxisome proliferator-activated receptors in ovarian tissue from naturally cycling and pseudopregnant rats," Biology of Reproduction, vol. 66, no. 5, pp. 15311539, 2002.

[68] M. Mohan, J. R. Malayer, R. D. Geisert, and G. L. Morgan, "Expression patterns of retinoid $\mathrm{X}$ receptors, retinaldehyde dehydrogenase, and peroxisome proliferator activated receptor gamma in bovine preattachment embryos," Biology of Reproduction, vol. 66, no. 3, pp. 692-700, 2002.

[69] A. Ibabe, A. Herrero, and M. P. Cajaraville, "Modulation of peroxisome proliferator-activated receptors (PPARs) by PPAR $\alpha$ and PPAR $\gamma$-specific ligands and by $17 \beta$-estradiol in isolated zebrafish hepatocytes," Toxicology in Vitro, vol. 19, no. 6, pp. 725735, 2005.

[70] C. E. Minge, B. D. Bennett, R. J. Norman, and R. L. Robker, "Peroxisome proliferator-activated receptor- $\gamma$ agonist rosiglitazone reverses the adverse effects of diet-induced obesity on oocyte quality," Endocrinology, vol. 149, no. 5, pp. 2646-2656, 2008.

[71] K. R. Dunning, M. R. Anastasi, V. J. Zhang, D. L. Russell, and R. L. Robker, "Regulation of fatty acid oxidation in mouse cumulus-oocyte complexes during maturation and modulation by PPAR agonists," PLoS ONE, vol. 9, no. 2, Article ID e87327, 2014.

[72] X. Xin, S. Yang, J. Kowalski, and M. E. Gerritsen, "Peroxisome proliferator-activated receptor $\gamma$ ligands are potent inhibitors of angiogenesis in vitro and in vivo," The Journal of Biological Chemistry, vol. 274, no. 13, pp. 9116-9121, 1999.

[73] H. Shu, B. Wong, G. Zhou et al., "Activation of PPAR $\alpha$ or $\gamma$ reduces secretion of matrix metalloproteinase 9 but not interleukin 8 from human monocytic THP-1 cells," Biochemical and Biophysical Research Communications, vol. 267, no. 1, pp. 345-349, 2000.

[74] T. Lovekamp-Swan, A. M. Jetten, and B. J. Davis, "Dual activation of PPAR $\alpha$ and PPAR $\gamma$ by mono-(2-ethylhexyl) phthalate in rat ovarian granulosa cells," Molecular and Cellular Endocrinology, vol. 201, no. 1-2, pp. 133-141, 2003.

[75] J. H. Ford, "Reduced quality and accelerated follicle loss with female reproductive aging-does decline in theca dehydroepiandrosterone (DHEA) underlie the problem?" Journal of Biomedical Science, vol. 20, no. 1, article 93, 2013.

[76] P. G. Artini, G. Simi, M. Ruggiero et al., "DHEA supplementation improves follicular microenviroment in poor responder patients," Gynecological Endocrinology, vol. 28, no. 9, pp. 669673, 2012.

[77] C. Tatone, F. Amicarelli, M. C. Carbone et al., "Cellular and molecular aspects of ovarian follicle ageing," Human Reproduction Update, vol. 14, no. 2, pp. 131-142, 2008.

[78] J.-C. Huang, W.-S. A. Wun, J. S. Goldsby, K. Egan, G. A. Fitzgerald, and K. K. Wu, "Prostacyclin receptor signaling and early embryo development in the mouse," Human Reproduction, vol. 22, no. 11, pp. 2851-2856, 2007.

[79] J. D. Veldhuis, G. Zhang, and J. C. Garmey, "Troglitazone, an insulin-sensitizing thiazolidinedione, represses combined stimulation by LH and insulin of de novo androgen biosynthesis by thecal cells in vitro," Journal of Clinical Endocrinology and Metabolism, vol. 87, no. 3, pp. 1129-1133, 2002.

[80] A. Rak-Mardyła and E. Drwal, "In vitro interaction between resistin and peroxisome proliferator-activated receptor $\gamma$ in porcine ovarian follicles," Reproduction, Fertility and Development, vol. 28, no. 3, pp. 357-368, 2014.

[81] Y. Cui, K. Miyoshi, E. Claudio et al., "Loss of the peroxisome proliferation-activated receptor gamma (PPAR $\gamma)$ does not affect mammary development and propensity for tumor formation but leads to reduced fertility," The Journal of Biological Chemistry, vol. 277, no. 20, pp. 17830-17835, 2002.

[82] E. Lord, B. D. Murphy, J. A. Desmarais, S. Ledoux, D. Beaudry, and M.-F. Palin, "Modulation of peroxisome proliferatoractivated receptor $\delta$ and $\gamma$ transcripts in swine endometrial tissue during early gestation," Reproduction, vol. 131, no. 5, pp. 929-942, 2006.

[83] L. Cammas, P. Reinaud, N. Bordas, O. Dubois, G. Germain, and G. Charpigny, "Developmental regulation of prostacyclin synthase and prostacyclin receptors in the ovine uterus and conceptus during the peri-implantation period," Reproduction, vol. 131, no. 5, pp. 917-927, 2006.

[84] Q. Wang, H. Fujii, and G. T. Knipp, "Expression of PPAR and RXR isoforms in the developing rat and human term placentas," Placenta, vol. 23, no. 8-9, pp. 661-671, 2002.

[85] H. Tasaki, L. Zhao, K. Isayama et al., "Profiling of circadian genes expressed in the uterus endometrial stromal cells of pregnant rats as revealed by DNA microarray coupled with RNA interference," Frontiers in Endocrinology, vol. 4, article 82, 2013.

[86] Y. Barak, M. C. Nelson, E. S. Ong et al., "PPAR $\gamma$ is required for placental, cardiac, and adipose tissue development," Molecular Cell, vol. 4, no. 4, pp. 585-595, 1999. 
[87] R. Asami-Miyagishi, S. Iseki, M. Usui, K. Uchida, H. Kubo, and I. Morita, "Expression and function of PPAR $\gamma$ in rat placental development," Biochemical and Biophysical Research Communications, vol. 315, no. 2, pp. 497-501, 2004.

[88] T. Fournier, V. Tsatsaris, K. Handschuh, and D. Evain-Brion, "PPARs and the placenta," Placenta, vol. 28, no. 2-3, pp. 65-76, 2007.

[89] G. Daoud, L. Simoneau, A. Masse, E. Rassart, and J. Lafond, "Expression of cFABP and PPAR in trophoblast cells: effect of PPAR ligands on linoleic acid uptake and differentiation," Biochimica et Biophysica Acta-Molecular and Cell Biology of Lipids, vol. 1687, no. 1-3, pp. 181-194, 2005.

[90] M. P. Kowalewski, A. Meyer, B. Hoffmann, S. Aslan, and A. Boos, "Expression and functional implications of peroxisome proliferator-activated receptor gamma $(\operatorname{PPAR} \gamma)$ in canine reproductive tissues during normal pregnancy and parturition and at antiprogestin induced abortion," Theriogenology, vol. 75, no. 5, pp. 877-886, 2011.

[91] L. Kadam, H. R. Kohan-Ghadr, and S. Drewlo, "The balancing act-PPAR- $\gamma$ 's roles at the maternal-fetal interface," Systems Biology in Reproductive Medicine, vol. 61, no. 2, pp. 65-71, 2015.

[92] K. Nadra, S. I. Anghel, E. Joye et al., "Differentiation of trophoblast giant cells and their metabolic functions are dependent on peroxisome proliferator-activated receptor $\beta / \delta$," Molecular and Cellular Biology, vol. 26, no. 8, pp. 3266-3281, 2006.

[93] Y. Barak, M. C. Nelson, E. S. Ong et al., "PPAR $\gamma$ is required for placental, cardiac, and adipose tissue development," Molecular Cell, vol. 4, no. 4, pp. 585-595, 1999.

[94] N. Kubota, Y. Terauchi, H. Miki et al., "PPAR gamma mediates high-fat diet-induced adipocyte hypertrophy and insulin resistance," Molecular Cell, vol. 4, no. 4, pp. 597-609, 1999.

[95] M. M. Parast, H. Yu, A. Ciric, M. W. Salata, V. Davis, and D. S. Milstone, "PPAR $\gamma$ regulates trophoblast proliferation and promotes labyrinthine trilineage differentiation," PLOS ONE, vol. 4, no. 11, Article ID e8055, 2009.

[96] A. Meher, D. Sundrani, and S. Joshi, "Maternal nutrition influences angiogenesis in the placenta through peroxisome proliferator activated receptors: a novel hypothesis," Molecular Reproduction and Development, vol. 82, no. 10, pp. 726-734, 2015.

[97] J. M. Gimble, G. M. Pighetti, M. R. Lerner et al., "Expression of peroxisome proliferator activated receptor mRNA in normal and tumorigenic rodent mammary glands," Biochemical and Biophysical Research Communications, vol. 253, no. 3, pp. 813817, 1998.

[98] D. Bonofiglio, S. Aquila, S. Catalano et al., "Peroxisome proliferator-activated receptor- $\gamma$ activates $\mathrm{p} 53$ gene promoter binding to the nuclear factor- $\kappa \mathrm{B}$ sequence in human MCF7 breast cancer cells," Molecular Endocrinology, vol. 20, no. 12, pp. 30833092, 2006.

[99] Y. Zhao, Y. S. Tan, M. J. Strynar, G. Perez, S. Z. Haslam, and C. Yang, "Perfluorooctanoic acid effects on ovaries mediate its inhibition of peripubertal mammary gland development in Balb/c and C57Bl/6 mice," Reproductive Toxicology, vol. 33, no. 4, pp. 563-576, 2012.

[100] F. Wang, S. E. Mullican, J. R. DiSpirito, L. C. Peed, and M. A. Lazar, "Lipoatrophy and severe metabolic disturbance in mice with fat-specific deletion of PPAR $\gamma$," Proceedings of the National Academy of Sciences of the United States of America, vol. 110, no. 46, pp. 18656-18661, 2013.

[101] H. Shi, J. Luo, J. Zhu et al., "PPAR $\gamma$ regulates genes involved in triacylglycerol synthesis and secretion in mammary gland epithelial cells of dairy goats," PPAR Research, vol. 2013, Article ID 310948, 10 pages, 2013.

[102] A. J. Apostoli, G. E. A. Skelhorne-Gross, R. E. Rubino et al., "Loss of PPAR $\gamma$ expression in mammary secretory epithelial cells creates a pro-breast tumorigenic environment," International Journal of Cancer, vol. 134, no. 5, pp. 1055-1066, 2014.

[103] S. D. Torre, V. Benedusi, R. Fontana, and A. Maggi, "Energy metabolism and fertility: a balance preserved for female health," Nature Reviews Endocrinology, vol. 10, no. 1, pp. 13-23, 2014.

[104] F. J. Broekmans and B. C. J. M. Fauser, "Diagnostic criteria for polycystic ovarian syndrome," Endocrine, vol. 30, no. 1, pp. 3-11, 2006.

[105] S. S. Lim, R. J. Norman, M. J. Davies, and L. J. Moran, “The effect of obesity on polycystic ovary syndrome: a systematic review and meta-analysis," Obesity Reviews, vol. 14, no. 2, pp. 95-109, 2013.

[106] R. A. Wild, "Dyslipidemia in PCOS," Steroids, vol. 77, no. 4, pp. 295-299, 2012.

[107] S. Hara, T. Takahashi, M. Amita, H. Igarashi, and H. Kurachi, "Usefulness of bezafibrate for ovulation induction in clomiphene citrate-resistant polycystic ovary syndrome patients with dyslipidemia: a prospective pilot study of seven cases," Gynecologic and Obstetric Investigation, vol. 70, no. 3, pp. 166172, 2010.

[108] R. Pasquali and A. Gambineri, "Insulin sensitizers in polycystic ovary syndrome," Frontiers of Hormone Research, vol. 40, pp. 83-102, 2013

[109] S. R. Joshi, "Saroglitazar for the treatment of dyslipidemia in diabetic patients," Expert Opinion on Pharmacotherapy, vol. 16, no. 4, pp. 597-606, 2015.

[110] X. Xie, X. Zhou, W. Chen et al., "L312, a novel PPAR $\gamma$ ligand with potent anti-diabetic activity by selective regulation," Biochimica et Biophysica Acta-General Subjects, vol. 1850, no. 1, pp. 62-72, 2015.

[111] T. Kariharan, G. Nanayakkara, K. Parameshwaran et al., "Central activation of PPAR-gamma ameliorates diabetes induced cognitive dysfunction and improves BDNF expression," Neurobiology of Aging, vol. 36, no. 3, pp. 1451-1461, 2015.

[112] E. Moutzouri, A. Kei, M. S. Elisaf, and H. J. Milionis, "Management of dyslipidemias with fibrates, alone and in combination with statins: role of delayed-release fenofibric acid," Vascular Health and Risk Management, vol. 6, no. 1, pp. 525-539, 2010.

[113] Q. Du, S. Yang, Y.-J. Wang, B. Wu, Y.-Y. Zhao, and B. Fan, "Effects of thiazolidinediones on polycystic ovary syndrome: a meta-analysis of randomized placebo-controlled trials," Advances in Therapy, vol. 29, no. 9, pp. 763-774, 2012.

[114] L. Mohiyiddeen, A. J. Watson, N. V. Apostolopoulos, R. Berry, K. I. Alexandraki, and E. B. Jude, "Effects of low-dose metformin and rosiglitazone on biochemical, clinical, metabolic and biophysical outcomes in polycystic ovary syndrome," Journal of Obstetrics and Gynaecology, vol. 33, no. 2, pp. 165-170, 2013.

[115] N. F. Vigerust, P. Bohov, B. Bjørndal et al., "Free carnitine and acylcarnitines in obese patients with polycystic ovary syndrome and effects of pioglitazone treatment," Fertility and Sterility, vol. 98, no. 6, pp. 1620-1626.e1, 2012.

[116] I. T. Abdel-Raheem, G. A. Omran, and M. A. Katary, "Irbesartan, an angiotensin II receptor antagonist, with selective PPARgamma-modulating activity improves function and structure of chemotherapy-damaged ovaries in rats," Fundamental and Clinical Pharmacology, vol. 29, no. 3, pp. 286-298, 2015. 
[117] T. N. Lovekamp and B. J. Davis, "Mono-(2-ethylhexyl) phthalate suppresses aromatase transcript levels and estradiol production in cultured rat granulosa cells," Toxicology and Applied Pharmacology, vol. 172, no. 3, pp. 217-224, 2001.

[118] E. K. Maloney and D. J. Waxman, "trans-Activation of PPARalpha and PPARgamma by structurally diverse environmental chemicals," Toxicology and Applied Pharmacology, vol. 161, no. 2, pp. 209-218, 1999.

[119] T. Kanayama, N. Kobayashi, S. Mamiya, T. Nakanishi, and J.I. Nishikawa, "Organotin compounds promote adipocyte differentiation as agonists of the peroxisome proliferator-activated receptor $\gamma /$ retinoid X receptor pathway," Molecular Pharmacology, vol. 67, no. 3, pp. 766-774, 2005.

[120] S. Takeuchi, T. Matsuda, S. Kobayashi, T. Takahashi, and H. Kojima, "In vitro screening of 200 pesticides for agonistic activity via mouse peroxisome proliferator-activated receptor (PPAR) $\alpha$ and PPAR $\gamma$ and quantitative analysis of in vivo induction pathway," Toxicology and Applied Pharmacology, vol. 217, no. 3, pp. 235-244, 2006.

[121] M. Kawano, X.-Y. Qin, M. Yoshida et al., "Peroxisome proliferator-activated receptor $\alpha$ mediates di-(2-ethylhexyl) phthalate transgenerational repression of ovarian Esrl expression in female mice," Toxicology Letters, vol. 228, no. 3, pp. 235-240, 2014. 


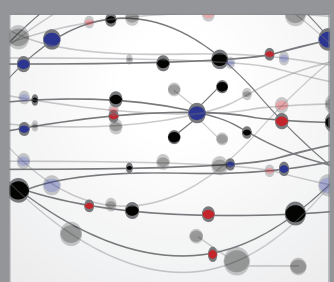

The Scientific World Journal
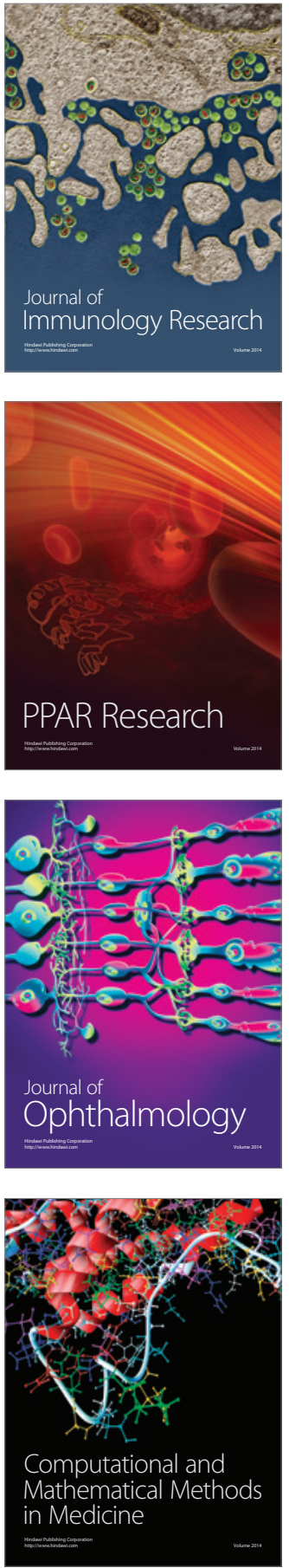

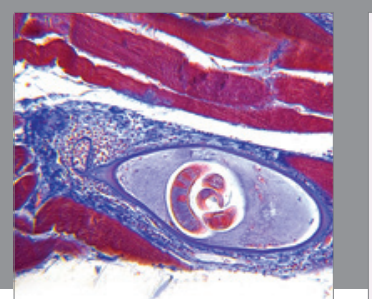

Gastroenterology Research and Practice

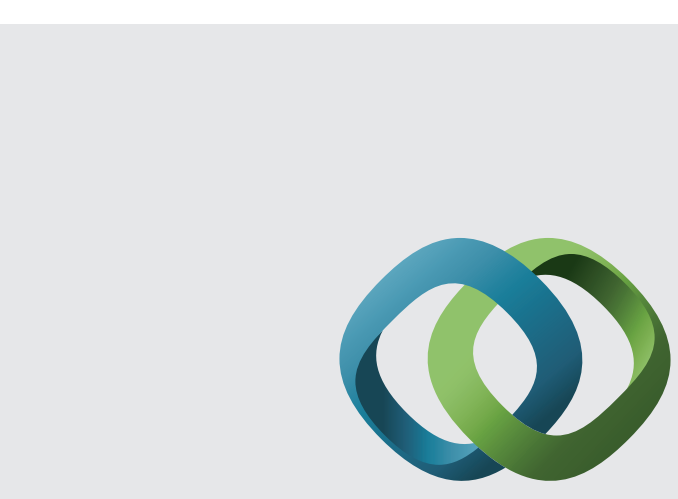

\section{Hindawi}

Submit your manuscripts at

http://www.hindawi.com
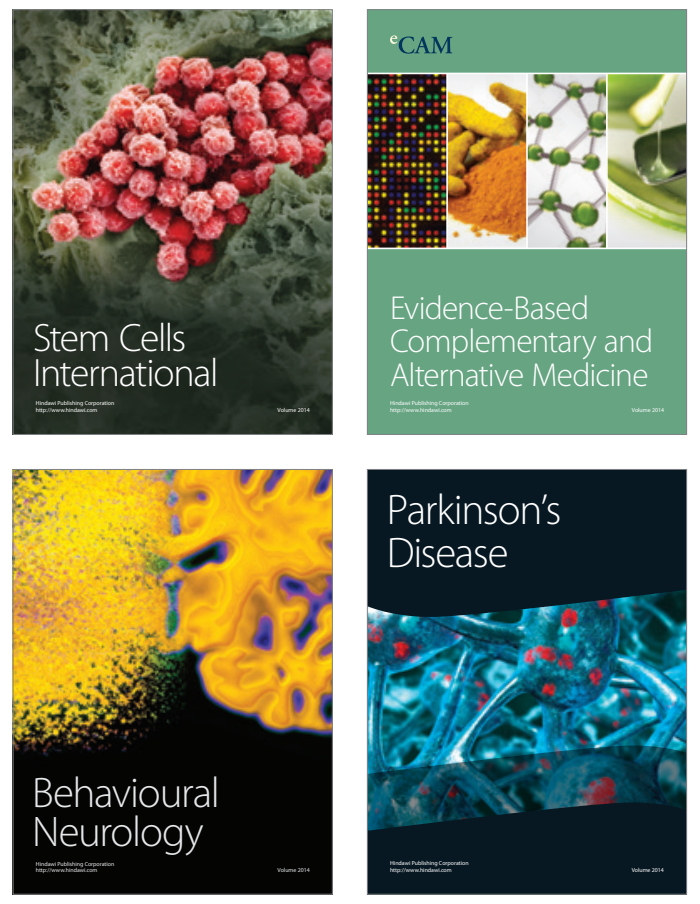
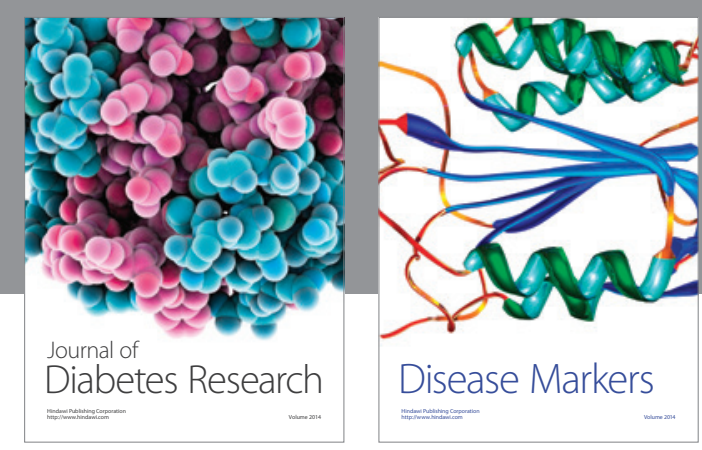

Disease Markers
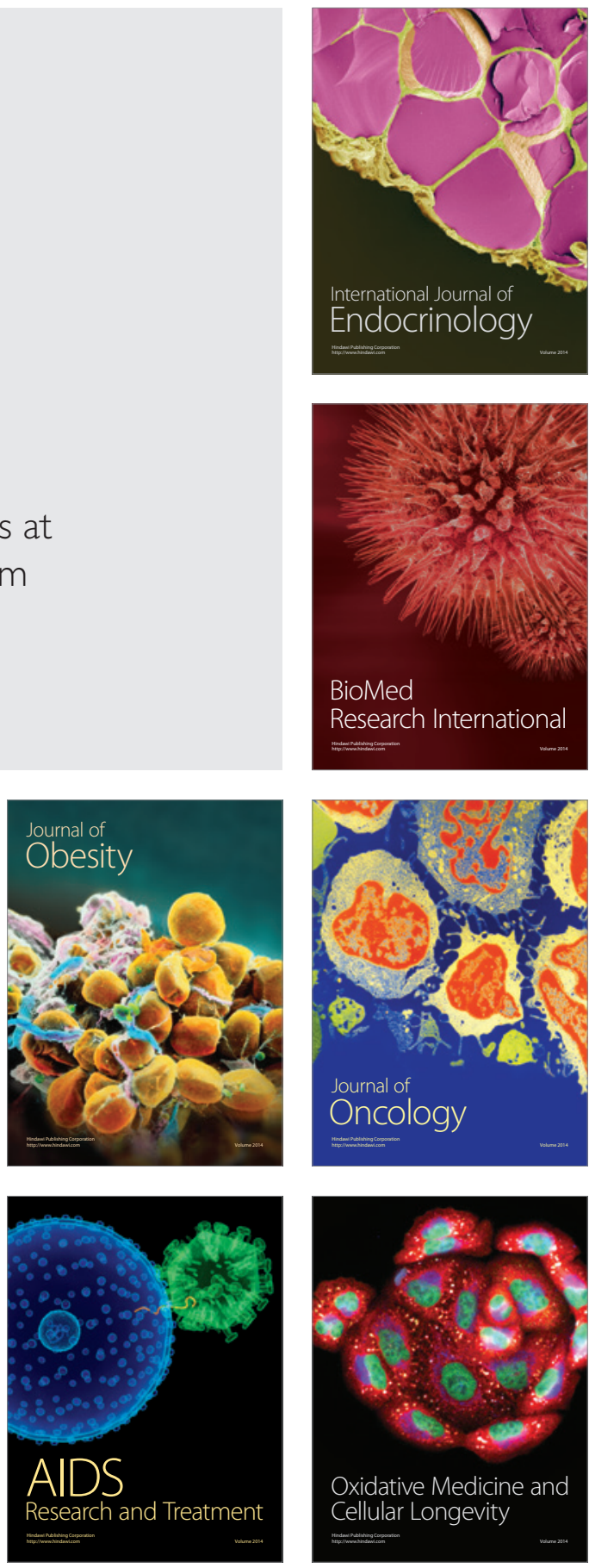